Romero M.L., Espinos A, Portolés JM, Hospitaler A and Ibañez C, Slender double-tube ultrahigh strength concrete-filled tubular columns under ambient temperature and fire, Engineering Structures 2015; 99: 536-545.

\title{
Slender double-tube ultra-high strength concrete-filled tubular columns under ambient temperature and fire
}

\author{
M. L. Romero ${ }^{a} *$, A. Espinos ${ }^{a}$, J.M. Portolés ${ }^{b}$, A. Hospitaler ${ }^{a}$ and C. Ibañez ${ }^{b}$ \\ ${ }^{a}$ Instituto de Ciencia y Tecnología del Hormigón (ICITECH), \\ Universitat Politècnica de València, Valencia, Spain \\ ${ }^{b}$ Department of Mechanical Engineering and Construction, \\ Universitat Jaume I, Castellón, Spain \\ * Corresponding author.e-mail address: mromero@mes.upv.es
}

\begin{abstract}
This paper presents the results of an experimental campaign where both the room temperature and the fire resistance of six double-tube concrete filled steel tubular slender columns with different combinations of concrete strength are studied. Firstly, the ultimate axial load of the specimens at room temperature was experimentally obtained and afterwards the fire resistance of such columns subjected to a $20 \%$ of their load bearing capacity was measured. Given the reduced number of experimental results found in the literature on slender concrete filled tubular columns with double steel tubular cross-sections, the main objective of this paper is to compare the behaviour of such innovative cross-sections under ambient and high temperatures. The influence of filling the inner ring with concrete on the fire performance of these columns is studied in this paper, as well as the variation of thicknesses of the outer and inner steel tubes. Despite the fact that the tested columns are not covered by the scope of Eurocode 4, the current simple calculation models were applied in this paper in order to assess the validity of the standard to this typology of columns, unsafe results being found.
\end{abstract}

Keywords: Concrete filled steel tubular column, Fire resistance, Double-tube, ultra-high strength concrete, Eurocode 4. 
Romero M.L., Espinos A, Portolés JM, Hospitaler A and Ibañez C, Slender double-tube ultrahigh strength concrete-filled tubular columns under ambient temperature and fire, Engineering Structures 2015; 99: 536-545.

\section{NOTATION}

HSS Hollow steel section

CFDST Concrete-filled dual steel tubes

CFST Concrete filled steel tube

D Diameter of the steel stube

$\mathrm{t} \quad$ thickness of the steel tube

,ext relating to the outer steel tube

int relating to the inner steel tube

$f_{\mathrm{c}} \quad$ Compressive cylinder strength of concrete at room temperature (test date)

$f_{\mathrm{s}} \quad$ Yield strength of reinforcing steel at room temperature

$f_{\mathrm{y}} \quad$ Yield strength of structural steel at room temperature

EC4 Eurocode 4

$N_{u} \quad$ Ultimate axial load at room temperature from tests

$N_{b, R d} \quad$ Design axial buckling load at room temperature from EC4 part 1.1

$N_{f i, R d} \quad$ Design axial buckling load in the fire situation from EC4 part 1.2

$\mathrm{N}_{\text {fire }} \quad$ Axial load applied in the fire test

FR Fire resistance time from tests

$\ell_{\theta} \quad$ Buckling length of the column

$\bar{\lambda} \quad$ Relative slenderness at room temperature

$E_{a, \theta} \quad$ Modulus of elasticity of structural steel at the temperature $\theta$

$E_{c, s e c, \theta} \quad$ Secant modulus of concrete at the temperature $\theta$

$E_{s, \theta} \quad$ Modulus of elasticity of reinforcing steel at the temperature $\theta$

$(E I)_{f i, e f f} \quad$ Effective flexural stiffness in the fire situation

$I_{i, \theta} \quad$ Second moment of area of the part $i$ of the cross-section at the temperature $\theta$

$N \quad$ Test load

$L \quad$ Column length

$\varphi_{i, \theta} \quad$ Reduction coefficient of the part "i" depending on the effect of thermal stresses

$\varphi_{s} \quad$ Reduction coefficient depending on the percentage of reinforcement

$\varphi_{\delta} \quad$ Reduction coefficient depending on the eccentricity

$\mu=N / N_{u} \quad$ Axial load level

$\theta_{i, e q} \quad$ Equivalent temperature of the part $i$ of the cross-section 
Romero M.L., Espinos A, Portolés JM, Hospitaler A and Ibañez C, Slender double-tube ultrahigh strength concrete-filled tubular columns under ambient temperature and fire, Engineering Structures 2015; 99: 536-545.

\section{INTRODUCTION}

Concrete-filled steel tubular (CFST) members are being increasingly used worldwide as composite columns in new building developments. However, the current European guidelines for member design in fire (EN1994-1-2, [1]) have been proved to be unsafe for columns with relative slenderness values higher than 0.5 . At the same time, the use of high strength concrete (HSC) is becoming popular thanks to the reduction of its technological costs, in such a way that even ultra-high strength concrete (UHSC) has been introduced recently. The use of this material presents great advantages, mainly in members subjected to considerably high compressive axial forces, as it occurs in columns of high-rise buildings and bridge piers. Nevertheless, it presents some disadvantages, such as its brittle behaviour at room temperature, the possibility of experiencing spalling at elevated temperatures and the fact that Eurocode 4 part 1-1 [2] is still limited to concrete grades up to $50 \mathrm{MPa}$.

The usage of high strength materials in columns reduces their cross-section while increasing the member slenderness, with the consequent buckling problems and detrimental effect to the fire resistance. For this reason, new innovative solutions are needed in order to guarantee that this type of columns produce the appropriate structural response.

In this paper, the initial results to characterize a novel type of cross-section (doubletube) are presented, which solves some of the previously referred problems and shortcomings, being possible to employ different concrete grades in the inner core and outer concrete ring. This would help to prevent spalling problems associated to UHSC by being subjected to lower temperatures in those parts of the column where it is found more useful. At the same time, the presence of an internal steel tube with a lower temperature would help to resist the second order effects in slender columns. 
Romero M.L., Espinos A, Portolés JM, Hospitaler A and Ibañez C, Slender double-tube ultrahigh strength concrete-filled tubular columns under ambient temperature and fire, Engineering Structures 2015; 99: 536-545.

According to previous investigations (Han et al [3] and Espinos et al [4]), the main source of the lack of coherence in Eurocode 4 Part 1-2 [1] when predicting the fire resistance of slender concrete-filled CHS columns is originated by a special local behaviour produced in the top end of the column between the concrete core and the steel tube during the fire scenario. However, other researchers (Bailey [5]) doubt if this local behaviour only appears in isolated columns and not in columns as part of a portal-frame.

The general behaviour of CFST columns during a fire can be described as follows: due to its higher thermal conductivity and its direct exposure to fire, the steel tube heats up more rapidly and consequently expands faster than the concrete core, Espinos et al. [4]. This difference of the axial deformation rate and the appearance of slip at the steel-concrete boundary lead to the loss of contact of the concrete core with the loading plate. Because of this, the axial load ratio of steel increases gradually up to a point where the entire applied load is sustained by the steel section (stage 1), Fig. 1.

This situation is maintained until the steel tube reaches its critical temperature and the local yielding of the steel section occurs (stage 2), Fig. 1. At this point, the steel tube starts to shorten, allowing the loading plate to contact back the concrete core. As the column shortens, the load sustained by the steel tube is progressively transferred to the concrete core (stage 3) and, as a consequence, the axial load ratio undergoes an inversion. At this point, the concrete core is the element of the column that shows more resistance, since the steel tube has lost its load-bearing capacity. As the inner temperature increases, the concrete core degrades slowly due to its low conductivity, but after a significant period of time the concrete core completely loses its strength and stiffness, leading to failure (stage 4), Fig. 1.

The current methods in Eurocode 4 Part 1-2 [1] can predict accurately this behaviour if the element has a low relative slenderness (in general less than 0.5), Aribert et al [6]. However, for slender CFST columns the behaviour is different, and the contribution of the 
Romero M.L., Espinos A, Portolés JM, Hospitaler A and Ibañez C, Slender double-tube ultrahigh strength concrete-filled tubular columns under ambient temperature and fire, Engineering Structures 2015; 99: 536-545.

concrete core does not appear completely. In these cases the failure is due to the overall buckling of the steel tube when trying to transfer the load to the concrete core. In such situation, the presence of concrete in comparison with an empty hollow section only affects the temperature distribution and not the mechanical resistance during the fire tests. This special local behaviour it is not accounted for in the Eurocode 4, thus creating an unsafe situation.

In Europe, a large amount of experimental work was conducted some time ago by CIDECT (International Committee for the Study and Development of Tubular Construction) on the fire resistance of normal strength CFST columns. Worldwide it has been also intensely investigated for years and numerous test programs have been carried out mainly for nonslender columns (Lie and Chabot [7] , Chabot and Lie [8], Kordina and Klingsch [10] , Park et al [11][12], Han et al [3]).

Recently, Romero et al [13][14] have completed a research project where 16 concentric and 24 eccentric loaded circular CFST slender columns were tested to measure the fire resistance, finding that for slender columns only a small fire resistance (FR) can be obtained, where the FR was lower than 30 min. They stated that if second order effects produced by the curvature in the steel tube are very large, they cannot be transferred to a brittle material as unreinforced concrete and thus the presence of concrete results of no utility in very slender elements. This study provided the evidence about some limitations in the Eurocode 4 simple calculation model when predicting the axial buckling load of slender concrete filled hollow steel sections at elevated temperatures, and suggested that the model should be revised in the future on the basis of these findings.

This work agreed with previous results from Renaud et al.[15] and Leskela [16] and led to a resolution of the CEN/TC 250/SC4 imposing an amendment to limit the relative slenderness at ambient temperature to 0.5 for the application of Annex $\mathrm{H}$ of this code. 
Romero M.L., Espinos A, Portolés JM, Hospitaler A and Ibañez C, Slender double-tube ultrahigh strength concrete-filled tubular columns under ambient temperature and fire, Engineering Structures 2015; 99: 536-545.

If the steel industry wants to maintain the profitability of concrete-filled hollow steel sections, they should incorporate fire resistance assessment methods for the innovative types of columns that provide higher fire resistance. Regarding them, steel cores inside the columns may increase significantly the fire resistance (FR) and lead to a higher load bearing capacity both at room temperature and in the fire situation. This is caused by the slower temperature increase in the steel core due to protection by the concrete filling.

Up to now the main work on this topic has been performed by the groups of Prof L.H. Han, Prof. X.L. Zhao and co-workers, where several papers have been published at room temperature and fire about the so-called "double-skin" CFT columns [17]-[26] where the inner CHS is empty. They stated that these composite columns could also have higher fire resistance than the regular CFST columns, due to the inner tubes being protected by the sandwiched concrete during fire.

However, other authors have proposed the solution to embed massive steel sections inside the core maintaining a high axial capacity for multi-story buildings. Neuenschwander et al [27] performed some fire tests reaching good structural fire behaviour (up to 179 min) although an important influence of 2nd order effects was observed depending on the load level. They affirmed that the load share of steel tube is redistributed to the core and it is mainly determining the structural behaviour of composite column in fire. Also Schaumann and Kleiböemer [28] carried out a large scale fire test on a composite column with embedded massive steel core. The column was composed of an outer circular hollow steel tube of dimensions $219.1 \times 4.5 \mathrm{~mm}$ and a centrically located massive steel core with a diameter of 140 mm, which was well protected against high temperatures by the concrete infill. With this configuration, the column attained 110 min fire resistance. 
Romero M.L., Espinos A, Portolés JM, Hospitaler A and Ibañez C, Slender double-tube ultrahigh strength concrete-filled tubular columns under ambient temperature and fire, Engineering Structures 2015; 99: 536-545.

In turn, Liew et al [29] have recently tested a new typology of cross sections called "double-tube" where the inner tube is filled also with concrete.

This paper presents the results of an experimental program where both double-skin and double-tube slender concrete-filled steel tubular columns have been tested and compared. Given the reduced number of experimental results found in the literature, the main objective of this paper is to compare the behaviour of such innovative cross-sections under ambient and high temperatures subjected to axial compression.

\section{EXPERIMENTAL STUDY AT ROOM TEMPERATURE}

\subsection{General}

The authors have performed several experimental campaigns to study the buckling resistance at room temperature of slender CFST columns with circular, square, rectangular or elliptical cross-sections [30]-[34]. However, CFDST sections have not been tested until now.

The tests presented in this paper are the initial results of an extensive experimental campaign (30 tests) where the effects of two parameters are analysed: strength of concrete (normal strength and ultra-high strength concrete) and the ratio between the thicknesses of the steel tubes. However, up to date only 6 experiments have been tested at room temperature and 6 under fire.

The sections were selected so as to maintain the total steel area in all the tests $( \pm 4 \%)$, being equal to that of a CFST column previously tested under fire by the authors; test C3 from [35]. Four of the column specimens were filled with concrete in the inner core (normal or ultra-high strength concrete, i.e. double-tube), while the other two columns were only filled in the outer concrete ring (i.e. double-skin). The dimensions of the typical cross-sections can be seen in Fig. 2.a and Table 1.a, while Fig. 2.b shows some pictures from the specimens. 
Romero M.L., Espinos A, Portolés JM, Hospitaler A and Ibañez C, Slender double-tube ultrahigh strength concrete-filled tubular columns under ambient temperature and fire, Engineering Structures 2015; 99: 536-545.

Nominal plain C30 and C150 grade concretes and steel S355 were used, although the real strengths obtained from the material tests are summarized in Table 1.a.

It is worth noting that the first three sections from Fig. 2.a had a thick inner tube and a thin outer tube, while in turn the other three sections had a thin inner tube and a thick outer tube.

This variation was decided given the interest to investigate what is more valuable from the practical point of view: to use a thin or thick outer tube. In a fire event it can be expected that the first group of sections (i.e. thick inner tube) perform better, while the second group of sections (i.e. thick outer tube) should be able to sustain higher loads at room temperature. This opposed behaviour needs to be confirmed, as an equilibrium in the design process should be reached.

\subsection{Column specimens and test setup}

All the specimens were manufactured at Universitat Politècnica de València (Spain) and tested later at Universitat Jaume I in Castellón (Spain). The buckling length of the columns was $3315 \mathrm{~mm}$ in all tests being tested under pinned-pinned (P-P) end conditions where a $300 \times 300 \times 15 \mathrm{~mm}$ steel plate was welded to both ends of the columns. All the specimens were tested in a $5000 \mathrm{kN}$ testing frame in a horizontal position, Fig. 2c. More details of the test setup can be found in [30]-[33]. Linear variable displacement transducers (LVDTs) were used to measure the deflection at five points along the column $(0.25 \mathrm{~L}, 0.375 \mathrm{~L}, 0.5 \mathrm{~L}, 0.625 \mathrm{~L}$ and 0.75L), Fig. 2d. Once the specimen was put in place, displacement control tests were carried out in order to measure the post-peak behaviour. 
Romero M.L., Espinos A, Portolés JM, Hospitaler A and Ibañez C, Slender double-tube ultrahigh strength concrete-filled tubular columns under ambient temperature and fire, Engineering Structures 2015; 99: 536-545.

\subsection{Material properties}

Steel tubes

Circular steel hollow sections were used in the experimental program for both the inner and outer steel tubes, Table 1 . The real yield strength of the hollow steel tubes $\left(f_{y}\right)$ was obtained for each column specimen by performing the corresponding coupon test. The modulus of elasticity of steel was set following the European standards with a value of 210 GPa.

\section{Concrete}

In this initial experimental program, two types of concrete were used, with nominal compressive strengths of $30 \mathrm{MPa}$ and $150 \mathrm{MPa}$. The concrete batches were prepared in a planetary mixer. In order to obtain the real compressive strength of concrete $\left(f_{c}\right)$, sets of concrete cylinders were prepared and cured in standard conditions during 28 days. All samples were tested on the same day as the column was tested, as shown in Table 1.

\subsection{Experimental results}

The maximum axial load of all specimens $\left(\mathrm{N}_{\mathrm{u}}\right)$ is listed Table 1 and the axial force versus mid-span displacement response for all tests is presented in Fig. 3.

The general trend of the curves results as expected: when the thicker tube is located in the outer part of the section, the maximum load increases although the load is concentric and the total steel area is approximately constant. This is due to the increase in the moment of inertia of the total section, which reduces the influence of the second order effects. Besides, if the inner CHS is filled also with concrete, the maximum load also increases. However, it must be highlighted that similar maximum loads are obtained for the tests C200-3-30_C114-8-30 
Romero M.L., Espinos A, Portolés JM, Hospitaler A and Ibañez C, Slender double-tube ultrahigh strength concrete-filled tubular columns under ambient temperature and fire, Engineering Structures 2015; 99: 536-545.

and C200-6-30_C114-3-00, where only small differences are found due to the diverse values of the steel yield strength.

Consequently, it can be stated that a double-tube column with the thicker tube in the inner position can reach almost the same buckling load (1627 kN), Table 1, as a double-skin CFT column with the thicker steel tube in the outer position and without inner concrete (1644 $\mathrm{kN})$.

Moreover, it is worth noting the reduced effect of using UHSC in the inner core in comparison with NSC (i.e tests C200-3-30_C114-8-150 and C200-3-30_C114-8-30). In fact, an increase of only a $9 \%$ in the load bearing capacity of the column is found despite the elevated cost of UHSC, which is approximately 5 times the cost of NSC.

\section{EXPERIMENTAL STUDY UNDER ELEVATED TEMPERATURE}

\subsection{General}

Even though a great number of fire tests can be found in the literature on CFST columns of circular and square section, the fire resistance of double-tube CFST slender columns where the inner steel tube is filled with concrete has not been yet investigated through experimental testing.

In this experimental program, six CFST columns equivalent to those previously tested at room temperature were subjected to a fire test.

Both the height of the column specimens and the boundary conditions (P-P) were maintained equal to those used at the ambient temperature tests. The axial load applied to the columns $\left(\mathrm{N}_{\text {fire }}\right.$ ) was approximately a $20 \%$ of their real load bearing capacity at room temperature $\left(\mathrm{N}_{\mathrm{u}}\right)$. Table 1.b lists the main characteristics of the tested specimens. 
Romero M.L., Espinos A, Portolés JM, Hospitaler A and Ibañez C, Slender double-tube ultrahigh strength concrete-filled tubular columns under ambient temperature and fire, Engineering Structures 2015; 99: 536-545.

\subsection{Test setup}

The experiments were performed in the testing facilities of AIDICO (Instituto Tecnológico de la Construcción) in Valencia, Spain. The tests were carried out in a $5 \times 3 \mathrm{~m}$ furnace equipped with a hydraulic jack of $1000 \mathrm{kN}$ maximum capacity and a total of 16 gas burners, located at mid-height of the furnace chamber. The test setup was similar to that used in previous experimental programs performed by the authors [13]. The columns were placed vertically inside the furnace, pinned $(\mathrm{P})$ at their bottom end and pinned $(\mathrm{P})$ at their top end. The load was on a first instance applied to the columns at room temperature, and afterwards and maintaining the load constant, the gas burners were activated, following the standard ISO 834 fire curve. A general view of the test setup can be seen in Fig. 4a and more details can be found at reference [13].

\subsection{Column specimens}

The length of the columns was $3180 \mathrm{~mm}$, although only $3036 \mathrm{~mm}$ were directly exposed to the fire inside the furnace, as indicated in Fig. 5a.

For each column specimen, two vent holes of $15 \mathrm{~mm}$ diameter were drilled in the outer steel hollow section wall at $100 \mathrm{~mm}$ from each column end. These vent holes were provided for relieving the water vapour pressure produced during the experiment. An additional hole, located near the bottom end of the columns, was used for connecting the thermocouple wires.

\subsection{Instrumentation}

The temperature evolution at different points of the column specimens was registered during the fire tests by means of a set of type $\mathrm{K}$ thermocouples (TC), arranged as given in Fig. 5b. Six thermocouples (A1 to A6) were located at the mid-length of the column, and identical thermocouples (B1 to B6 and C1 to C6) were located at 1/4 and 3/4 times the height of the 
Romero M.L., Espinos A, Portolés JM, Hospitaler A and Ibañez C, Slender double-tube ultrahigh strength concrete-filled tubular columns under ambient temperature and fire, Engineering Structures 2015; 99: 536-545.

column, respectively. Thermocouples 1 and 6 were located at the outer steel tube exposed surface, while the other 4 thermocouples (2 to 5) were embedded in the concrete core. Thermocouple 3 was attached to the outer surface of the inner steel tube. Additionally, two more thermocouples (A7-A8) were added in the section A-A' at 90 degrees being equivalent to $\mathrm{A} 2$ and $\mathrm{A} 3$ respectively.

The temperature inside the furnace chamber was automatically registered and controlled during the tests by means of 6 plate thermocouples and a pressure sensor, Fig. 4b. The axial elongation at the top end of the columns was measured during the tests by means of a LVDT located outside the furnace.

\subsection{Material properties}

Steel tubes

The same steel tubes as those used for the room temperature tests were employed in the fire tests. The real yield strength $\left(f_{\mathrm{y}}\right)$ of the hollow steel tubes is the same than in room temperature(see Table 1b).

\section{Concrete}

Table $1 \mathrm{~b}$ lists the real cylinder compressive strength of concrete $\left(f_{c}\right)$ for all the specimens, where calcareous aggregates were used in the concrete mix. The concrete cylinders were tested on the same day of the column fire test.

\subsection{Experimental results}

The typical failure observed in all the columns was overall buckling, while no local buckling was observed at mid-height of the column or near the column ends. 
Romero M.L., Espinos A, Portolés JM, Hospitaler A and Ibañez C, Slender double-tube ultrahigh strength concrete-filled tubular columns under ambient temperature and fire, Engineering Structures 2015; 99: 536-545.

The evolution of the axial displacement measured at the top end of the column along the fire exposure time is plotted in Fig. 6. The resulting fire resistance time (FR) expressed in minutes is listed in Table 1.b.

Additionally, a CFT column tested in a previous campaign by the authors (C3 from [35]) is included in this figure in order to compare the effect of splitting the total steel area into two different steel tubes, i.e. this column has the same total steel area using a single CHS tube with a diameter of $193.7 \mathrm{~mm}$ and a thickness of $8 \mathrm{~mm}$.

The axial displacement versus time curve obtained for column C3 presents in Fig. 6 a shorter concrete plateau in the third stage of the curve described in Fig. 1. This is due to the high slenderness of the column.

The axial displacement versus time curve obtained for the other six specimens tested presents some variations in the shape of the typical four-part curve, which depends on the type of cross-section for each particular test (i.e. different configuration). The first two stages can be clearly identified in all the curves plotted in Fig. 6; the first stage of these curves corresponding to the elongation of the steel tube and the second stage corresponding to the axial shortening of the column which occurs when the steel tube starts to yield. Subsequently, the load is transferred to the outer ring of concrete which plays an important role in the mechanical behaviour of the specimens.

\section{Configuration "thick outer steel tube-thin inner steel tube"}

If the inner steel tube is very thin (tests C200-6-30_C114-3-30 and C200-6-30_C114-3150), the increment of the fire resistance is minor in comparison with the single CFT column, test C3. The interpretation is that the column fails due to overall buckling previously to transfer the load to the inner steel tube, since the load is too high to be sustained by the slender inner composite column. It is clear that in these cases the outer thick tube becomes useless in the fire situation, as it is exposed to the higher temperatures and therefore its 
Romero M.L., Espinos A, Portolés JM, Hospitaler A and Ibañez C, Slender double-tube ultrahigh strength concrete-filled tubular columns under ambient temperature and fire, Engineering Structures 2015; 99: 536-545.

degradation is faster. This is the opposite behaviour than that observed at room temperature, where the configuration with thick outer steel tubes resulted in a higher buckling capacity.

It is also worth noting that although the load level applied to all the columns was the same (20\% of their maximum capacity at room temperature), the value of the load applied to the columns was different (i.e. higher for those columns with a higher axial capacity), and therefore the resulting fire resistances were slightly influenced.

This is the reason why the test with empty inner steel tube (C200-6-30_C114-3-00) achieved a higher fire resistance than the double-tube specimens, as the applied load was 19\% lower than the case filled with NSC.

\section{$\underline{\text { Configuration "thin outer steel tube-thick inner steel tube" }}$}

What is really important from Fig. 6 is the behaviour of the three tests where the inner steel tube is thicker (C200-3-30-C114-8-XX), as a new "stage 5" appears. In these tests, the inner steel tube starts to elongate again after the column shortening because it heats up at a lower rate than the outer tube (which again becomes useless in the fire situation).

This effect can be seen in the three tests, where the resulting fire resistance time increases between 1.6 and 2.3 times while the load applied to columns with thicker inner tubes was approximately an $85 \%$ of that of the columns with a thicker outer tube.

Surprisingly, the effect of filling the inner core with UHSC (138 MPa) produces a lower fire resistance. The main reason is because the axial load applied in this test was higher than that applied to the case where the inner core was filled with normal strength concrete (44 $\mathrm{MPa}$ ). As a result, it can be inferred that the inner concrete core is not functional in these slender columns and it has only the effect of reducing the temperatures in the inner steel tube. Distribution of Temperatures in the steel tubes

Fig. 7 shows the measurement of temperatures at the thermocouples located in the surface of both inner and outer steel tubes for the six fire tests. 
Romero M.L., Espinos A, Portolés JM, Hospitaler A and Ibañez C, Slender double-tube ultrahigh strength concrete-filled tubular columns under ambient temperature and fire, Engineering Structures 2015; 99: 536-545.

It can be seen that the temperatures of all the outer tubes are similar and no significant difference is observed in spite of some the existence of small variations. However, the temperatures at the inner steel tubes are very dependent on the configuration.

This graph helps to understand the reason of the higher fire resistance which presents those tests with a configuration "thin outer steel tube-thick inner steel tube". The inner steel tube fails within a temperature range of $500^{\circ} \mathrm{C}$. It can be stated that the load is totally transferred to the inner tube, and it fails only when the strength of inner tubes is reduced drastically.

For the tests with a configuration "thick outer steel tube-thin inner steel tube", two different behaviours are observed:

-The double-skin test (i.e.C200-6-30-C114-3-0) presents also the failure around $500{ }^{\circ} \mathrm{C}$. It is worth noting that this column is subjected to the same load than the column specimen C2003-30-C114-8-30 which presents a three times higher fire resistance. In this case the effect of the inner concrete justifies that this temperature is achieved later.

- The double-tube tests (i.e. C200-6-30-C114-3-30 and C200-6-30-C114-3-150) present the failure when the inner steel tube has reached only a reduced temperature of around 200-300 ${ }^{\circ} \mathrm{C}$. It confirms that the transference of load between the outer and the inner tube is not properly obtained in these cases. This can only be justified due the high slenderness of the inner composite tube which is not able to resist the total load applied to the column. 
Romero M.L., Espinos A, Portolés JM, Hospitaler A and Ibañez C, Slender double-tube ultrahigh strength concrete-filled tubular columns under ambient temperature and fire, Engineering Structures 2015; 99: 536-545.

\section{APPLICATION OF CURRENT DESIGN RULES TO CFDST COLUMNS}

Despite the fact that the tested columns are not covered by the scope of Eurocode 4, the current simple calculation models are intended to be applied in this section in order to asses the validity of the standard to this typology of columns.

\subsection{Room temperature design}

In this section, the simplified method of design in Clause 6.7.3 of EN 1994-1-1 [2] will be assessed against the results of the room temperature tests carried out in this experimental program. For members in axial compression, the design axial buckling load at room temperature can be obtained through the corresponding buckling curves according to Clause 6.7.3.5(2) from [2]. It defines that the maximum axial capacity of a CFST column $\left(\mathrm{N}_{\mathrm{b}, \mathrm{Rd}}\right)$ should be computed as:

$$
N_{b, R d}=\chi \cdot N_{p l, R d}
$$

where $\chi$ is the reduction factor given in EN 1993-1-1 [38] in terms of the relative slenderness $\bar{\lambda}$ from the corresponding buckling curve, and $N_{p l, R d}$ is the plastic resistance of the composite section according to 6.7.3.2(1).

The relative slenderness $\bar{\lambda}$ is defined in Eurocode 4 as:

$$
\bar{\lambda}=\sqrt{\frac{N_{p l}}{N_{c r}}}=\sqrt{\frac{A_{c} f_{c}+A_{s} f_{y}}{\frac{\pi^{2} E I}{L^{2}}}}
$$

where $\mathrm{EI}=\mathrm{E}_{\mathrm{s}} \mathrm{I}_{\mathrm{s}}+0.6 \mathrm{E}_{\mathrm{cm}} \cdot \mathrm{I}_{\mathrm{C}}$, and $\mathrm{I}_{\mathrm{s}}$ and $\mathrm{I}_{\mathrm{c}}$ are the second moment of inertia of the steel tube and the concrete core respectively; $E_{\mathrm{s}}$ is the modulus of elasticity of steel; and $\mathrm{E}_{\mathrm{cm}}$ is the secant modulus of elasticity of concrete. 
Romero M.L., Espinos A, Portolés JM, Hospitaler A and Ibañez C, Slender double-tube ultrahigh strength concrete-filled tubular columns under ambient temperature and fire, Engineering Structures 2015; 99: 536-545.

As this code does not allow the possibility to use double-tube configuration, the inner steel tube has been considered as an inner reinforcement, selecting accordingly the curves " $\mathrm{a}$ " or "b" from Table 5.5 in EN 1994-1-1 [2] in terms of the geometrical steel ratio. The results are summarized in Table $1\left(\mathrm{~N}_{\mathrm{b}, \mathrm{Rd}}\right)$ and Fig. 8a.

As it can be seen, the method in EC4 provides unsafe results on average for all the columns with an error around 15\%. No special trend is observed in terms of the steel distribution or strength of concrete.

With all the exposed above, it can be concluded that the method in EC4 for members in axial compression does not provide accurate results for evaluating the buckling resistance of double steel tube concrete-filled tubular columns. Further tests, both numerical and experimental, would be needed for evaluating the accuracy of EC4 method when ultra-high strength concrete is used also in the outer ring of the double tube.

\subsection{Fire resistance evaluation}

In this section, the fire test results will be employed to study and discuss the current provisions of EN 1994-1-2 [1]. Clause 4.3.5.1 of this standard presents a general simple calculation model for composite columns, which provides a method for calculating the design value of the buckling resistance of columns subjected to concentric axial loads in the fire situation. Although concrete-filled dual steel tubular column sections are not included in EC4, the application of the method to CFDST columns will be assessed in this section.

As part of the method, the effective flexural stiffness of the columns needs to be calculated, being defined in Clause 4.3.5.1(5) as:

$(E I)_{f i, e f f}=\sum_{j}\left(\varphi_{a, \theta} E_{a, \theta} I_{a, \theta}\right)+\sum_{k}\left(\varphi_{s, \theta} E_{s, \theta} I_{s, \theta}\right)+\sum_{m}\left(\varphi_{c, \theta} E_{c, \text { sec }, \theta} I_{c, \theta}\right)$ 
Romero M.L., Espinos A, Portolés JM, Hospitaler A and Ibañez C, Slender double-tube ultrahigh strength concrete-filled tubular columns under ambient temperature and fire, Engineering Structures 2015; 99: 536-545.

The evaluation of this equation requires the definition of a set of reduction coefficients $\left(\varphi_{i, \theta}\right)$ to account for the effect of the thermal stresses. Nevertheless, the values of these coefficients are not specified in the code for CFT columns. In the absence of these values, different assumptions have been suggested in the design guidance, as to take them as equal to unity or to use the values in Annex G for partially encased steel sections [36][37]. As the possibility to use double-tube configuration is not accounted for in the code, the same values of the reduction coefficients have been used for both inner and outer steel tubes. Eq (3) has been adapted for the configuration of CFDST as follows:

$$
\begin{aligned}
& (E I)_{f i, e f f}=\sum_{j}\left(\varphi_{a, \text { outer }, \theta} E_{a, \text { outer }, \theta} I_{a, \text { outer }, \theta}\right)+\sum_{k}\left(\varphi_{c, \text { outer }, \theta} E_{c, \text { outer }, \text { sec }, \theta} I_{c, \text { outer }, \theta}\right)+ \\
& +\sum_{l}\left(\varphi_{a, \text { inner }, \theta} E_{a, \text { inner }, \theta} I_{a, \text { inner }, \theta}\right)+\sum_{m}\left(\varphi_{c, \text { inner }, \theta} E_{c, \text { inner }, \text { sec }, \theta} I_{c, \text { inner }, \theta}\right)
\end{aligned}
$$

For the six columns, the test results are compared with the predictions from EC4 simple calculation model, in terms of the axial buckling load at the time of failure. For that purpose, the cross-sectional temperature field at the time of test failure is previously obtained for all the columns using the measured temperatures, and afterwards the buckling resistance is obtained as given in Clause 4.3.5.1 of EC4.

For obtaining the temperature distribution at the time of failure, the column crosssection was subdivided into a number of concentric circular layers of the same thickness, in particular one layer for each steel tube, one layer for the outer concrete ring and two layers for the inner concrete core. The temperatures at the different layers were obtained by using linear interpolation from the measured temperatures at the locations of the thermocouples.

Once the temperature distribution at the time of failure was obtained, the buckling resistance of all the tested columns was calculated by means of the described method. The results are summarized in Table 2, where the two options studied have been divided into two 
Romero M.L., Espinos A, Portolés JM, Hospitaler A and Ibañez C, Slender double-tube ultrahigh strength concrete-filled tubular columns under ambient temperature and fire, Engineering Structures 2015; 99: 536-545.

columns: reduction coefficients equal to unity and reduction coefficients from Annex G. In this table, the errors are computed as the test value divided by the EC4 prediction. A comparison between the calculated buckling loads and the test loads can be seen graphically in Fig. 8b.

As it can be seen, the simple calculation model in EC4 produced unsafe results using both assumptions for the flexural stiffness reduction coefficients, with an average value of the error equal to 0.82 with the former (unity coefficients) and 0.90 with the latter (Annex G). It is worth noting that the columns tested had a high slenderness in all cases. It can be observed that the predictions were more accurate for those cases filled with NSC, while for those filled with UHSC the predictions were highly non-conservative.

Therefore, it can be stated that the code produces unsafe results for concentrically loaded slender CFDST columns, being unacceptable for cases using UHSC. For those cases filled with NSC, unsafe predictions are obtained when the effect of the thermal stresses is neglected (i.e. flexural stiffness reduction coefficients equal to unity), but tolerable results are found when those coefficients are taken from Annex G.

Nevertheless, it must be reminded that these correction coefficients are not prepared to be used for CFDST columns, but have been applied here in the lack of specific guidance. Therefore, it is suggested that specific correction coefficients are derived in the future based on the results of parametric studies.

\section{SUMMARY AND CONCLUSIONS}

The results of an experimental program on slender dual steel tubular columns filled with normal and ultra-high concrete under room and elevated temperatures have been presented in this paper. Given the reduced number of experiments found in the literature, this work provides novel results to the research community. The test parameters covered in this 
Romero M.L., Espinos A, Portolés JM, Hospitaler A and Ibañez C, Slender double-tube ultrahigh strength concrete-filled tubular columns under ambient temperature and fire, Engineering Structures 2015; 99: 536-545.

experimental program were the influence of the strength of concrete in the inner ring and the variation of thicknesses of the outer and inner steel tubes, being the objective to study the influence on the fire resistance and load bearing capacity. Six tests were performed at room temperature, while other six fire tests were also carried out over equivalent column specimens.

From the test results at room temperature, it was found that a double-tube column with the thicker tube in the inner position can reach almost the same buckling load than a doubleskin CFT column with the thicker steel tube in the outer position and without inner concrete.

It results also noteworthy the reduced effect presented by the UHSC in the inner core in comparison with NSC.

In the fire situation, it was found that the results depend on the configuration of the section. If the inner steel tube is very thin, the increment of the fire resistance is minor in comparison with the single CFT column. However, if the inner steel tube is thick, a new "stage 5" appears where the inner steel tube starts to elongate again after the column shortening, producing an increment in the fire resistance.

It is worth noting that the tested columns are not covered by the scope of Eurocode 4, but the application of current design rules to CFDST columns was of high interest to assess the validity of the standard to this typology of columns. Using the tests results, the existing design rules have been assessed both for room temperature and fire. Within the limited cases of this study, it can be initially inferred that the method in EC4 Part 1.1 for members in axial compression provide unsafe results for evaluating the buckling resistance of CFDST columns, although further tests are needed for evaluating the method in a more reliable manner.

Furthermore, the simple calculation model in EC4 Part 1.2 (fire) produces also unsafe results. When comparing against the fire tests carried out in this research, unsafe results were obtained for concentrically loaded columns using both flexural stiffness reduction coefficients 
Romero M.L., Espinos A, Portolés JM, Hospitaler A and Ibañez C, Slender double-tube ultrahigh strength concrete-filled tubular columns under ambient temperature and fire, Engineering Structures 2015; 99: 536-545.

equal to unity and those taken from the Annex G, although the unconservativeness was more evident for those cases filled with UHSC.

The main conclusion which can be drawn from this experimental investigation is that a good design strategy for CFT columns could be to split thick CHS tubes in two different steel tubes with the same total steel area (and thus similar cost), but placing the thinner CHS in the outer part of the section and the thicker CHS in the inner part, so as to be thermally protected. Both rings should be filled up with concrete.

However, a reduced number of tests have been performed up to date, and more experiments and extensive numerical modelling should be performed to achieve reliable results. It is also worth noting that the conclusions achieved in the paper could be different for larger sections existing in some real structures (outer diameter equal to $1000 \mathrm{~mm}$ ) and the size effect should be taken into account in further studies.

Just to go in depth in this issue, the authors have performed a numerical investigation to study the size effect. Using a previously validated numerical model developed by the authors [4], a column with external tube 1103x6 mm and internal tube 1000x30 mm was simulated. The column was designed to be equivalent to specimen C200-3-30-C114-8-30, with the same member slenderness (0.83) and applied load level (20\% of its ultimate capacity at room temperature). The strength of the materials (steel and concrete) was the same as that of specimen C200-3-30-C114-8-30. The resulting column had a length of $19200 \mathrm{~mm}$, in order to maintain the same slenderness, which means a high computational cost. The analysed column had an outstanding fire resistance of 470 minutes, in comparison to column C200-3-30-C1148-30, which lasted 104 minutes. Despite the member slenderness and load level of the two specimens was similar; the temperature rise in the wider column was slower due to its lower section factor (A/V), which was a 15\% of that of column C200-3-30-C114-8-30. As the external diameter of the column increases, the section factor becomes lower (i.e. lower 
Romero M.L., Espinos A, Portolés JM, Hospitaler A and Ibañez C, Slender double-tube ultrahigh strength concrete-filled tubular columns under ambient temperature and fire, Engineering Structures 2015; 99: 536-545.

exposed surface for the same volume) and thus the section heats up slower, increasing the fire resistance time.

Therefore, this preliminary study confirms that there is a size effect and thus further studies would be needed in order to generalize the conclusions drawn in this paper to other section sizes. However, they cannot be extended without an extensive parametrical study, which will be in the scope of a future paper.

\section{ACKNOWLEDGEMENTS}

The authors would like to express their sincere gratitude to the Spanish Ministry of Economy and Competitivity through the project BIA2012-33144 and to the European Community for the FEDER funds.

\section{REFERENCES}

[1] CEN. EN 1994-1-2, Eurocode 4: Design of composite steel and concrete structures. Part 1-2: General rules - Structural fire design. Brussels, Belgium: Comité Européen de Normalisation; 2005.

[2] CEN. EN 1994-1-1, Eurocode 4: Design of composite steel and concrete structures. Part 1-1: General rules and rules for buildings. Brussels, Belgium: Comité Européen de Normalisation; 2004.

[3] Han L, Yang Y, Xu L. An experimental study and calculation on the fire resistance of concrete-filled SHS and RHS columns. Journal of constructional steel research 2003; 59(4):427-452.

[4] Espinos A, Romero M, Hospitaler A. Advanced model for predicting the fire response of concrete filled tubular columns. Journal of constructional steel research 2010; 66(89):1030-1046. 
Romero M.L., Espinos A, Portolés JM, Hospitaler A and Ibañez C, Slender double-tube ultrahigh strength concrete-filled tubular columns under ambient temperature and fire, Engineering Structures 2015; 99: 536-545.

[5] Bailey C, Effective lengths of concrete-filled steel square hollow sections in fire, Proc. Instn Civ. Engrs Structs \& Bldgs, 2000, 140, May, 169-178.

[6] Aribert JM, Renaud C, Zhao B. Simplified fire design for composite hollow-section columns. Structures \& Buildings 2008; 161:325-336.

[7] Lie TT, Chabot M. Experimental studies on the fire resistance of hollow steel columns filled with plain concrete. Internal report No. 611. Ottawa, Canada: Institute for Research in Construction, National Research Council of Canada (NRCC); 1992.

[8] Chabot M, Lie TT. Experimental studies on the fire resistance of hollow steel columns filled with bar-reinforced concrete. Internal report No. 628. Ottawa, Canada: Institute for Research in Construction, National Research Council of Canada (NRCC); 1992.

[9] Lie TT. Fire resistance of circular steel columns filled with bar-reinforced concrete. Journal of Structural Engineering-ASCE 1994; 120(5):1489-1509.

[10] Kordina K, Klingsch W. Fire resistance of composite columns of concrete filled hollow sections. CIDECT Research Project 15C1/C2-83/27. Cologne, Germany: Comité International pour le Développement et l'Etude de la Construction Tubulaire; 1983.

[11] Park S, Choi S, Chung K. A Study on the fire-resistance of concrete-filled steel square tube columns without fire protection under constant central axial loads. Steel And Composite Structures 2008; 8(6):491-510.

[12] Park S, Chung K, Choi S. 2007. A study on failure prediction and design equation of concrete filled square steel tube columns under fire condition. International Journal of Steel Structures 7(3):183-191.

[13] Romero, M.L., Moliner, V., Espinos, A., Ibañez, C., Hospitaler, A. Fire behavior of axially loaded slender high strength concrete-filled tubular columns, Journal of Constructional Steel Research 2011; 67: 1953-1965. 
Romero M.L., Espinos A, Portolés JM, Hospitaler A and Ibañez C, Slender double-tube ultrahigh strength concrete-filled tubular columns under ambient temperature and fire, Engineering Structures 2015; 99: 536-545.

[14] Moliner V, Espinos A, Romero ML, Hospitaler A. Fire behavior of eccentrically loaded slender high strength concrete-filled tubular columns. Journal of Constructional Steel Research 2013; 83:137-146.

[15] C. Renaud, Improvement and Extension of the Simple Calculation Method for Fire Resistance of Unprotected Concrete Filled Hollow Columns, CIDECT Research Project 15Q, Final report, CTICM, France, 2004.

[16] Leskela, M.V., Background document to New Annex H/EN 1994-1-2. Draft 4.10.2010 prepared for the meeting in Valencia. University of Oulu, Finland, 2010.

[17] Zhao X, Han L. 2006 "Double skin composite construction". Progress in structural engineering and materials;8(3):93-102

[18] Elchalakani M, Zhao XL, Grzebieta R. 2002, “Tests on concrete filled double-skin (CHS outer and SHS inner) composite short columns under axial compression”. Thin-walled structures;40(5):415-441.

[19] Lu H, Han L, Zhao X. 2010, "Fire performance of self-consolidating concrete filled double skin steel tubular columns: Experiments". Fire safety journal;45(2):106-115.

[20] Xiao-Ling Zhao, Le-Wei Tong, Xing-Yi Wang, CFDST stub columns subjected to large deformation axial loading, Engineering Structures 2010; 32(3): 692-703.

[21] Hui Lu, Lin-Hai Han, Xiao-Ling Zhao, Fire performance of self-consolidating concrete filled double skin steel tubular columns: Experiments, Fire Safety Journal 2010; 45(2): 106-115.

[22] Hong Huang, Lin-Hai Han, Zhong Tao, Xiao-Ling Zhao, Analytical behaviour of concrete-filled double skin steel tubular (CFDST) stub columns, Journal of Constructional Steel Research 2010; 66(4): 542-555. 
Romero M.L., Espinos A, Portolés JM, Hospitaler A and Ibañez C, Slender double-tube ultrahigh strength concrete-filled tubular columns under ambient temperature and fire, Engineering Structures 2015; 99: 536-545.

[23] Hui Lu, Xiao-Ling Zhao, Lin-Hai Han, Testing of self-consolidating concrete-filled double skin tubular stub columns exposed to fire, Journal of Constructional Steel Research 2010; 66(8-9): 1069-1080.

[24] Hui Lu, Xiao-Ling Zhao, Lin-Hai Han, Testing of self-consolidating concrete-filled double skin tubular stub columns exposed to fire, Journal of Constructional Steel Research 2010; 66(8-9): 1069-1080.

[25] Zhong Tao, Lin-Hai Han, Xiao-Ling Zhao, Behaviour of concrete-filled double skin (CHS inner and CHS outer) steel tubular stub columns and beam-columns, Journal of Constructional Steel Research 2004; 60(8): 1129-1158.

[26] Zhong Tao, Lin-Hai Han, Behaviour of concrete-filled double skin rectangular steel tubular beam-columns, Journal of Constructional Steel Research 2006 ; 62(7): 631-646 .

[27] Neuenschwander M., Knobloch M., Fontana M. Fire behaviour of concrete filled circular hollow section columns with massive steel core, Proceedings of the International Colloquium Stability and Ductility of Steel Structures SDSS, September 8-10, 2010, Rio de Janeiro, Brazil.

[28] Schaumann P., Kleiböemer I., Experimentelle Untersuchungen zum Trag- und Erwärmungsverhalten von Verbundstützen mit massivem Einstellprofil im Brandfall" / "Experimental investigations on the structural and thermal behaviour of composite columns with embedded massive steel core” ( In German), 19. DASt-Kolloqium, October 2014, Hannover, Germany (In press).

[29] Liew, Xiong D X. 2011, “Experimental investigation on tubular columns infilled with ultra-high strength concrete”. In: Tubular Structures XIII. Boca Raton: Crc Press-Taylor \& Francis Group; 637-645. 
Romero M.L., Espinos A, Portolés JM, Hospitaler A and Ibañez C, Slender double-tube ultrahigh strength concrete-filled tubular columns under ambient temperature and fire, Engineering Structures 2015; 99: 536-545.

[30] Portoles J M, Romero M L, Bonet J L, Filippou F C. Experimental study of high strength concrete-filled circular tubular columns under eccentric loading. Journal of constructional steel research 2011; 67(4):623-633.

[31] Portoles JM, Serra E, Romero ML. Influence of ultra-high strength infill in slender concrete-filled steel tubular columns. Journal of constructional steel research 2013; 86:107-114.

[32] Hernández-Figueirido D, Romero ML, Bonet JL, Montalvá JM. Ultimate capacity of rectangular concrete-filled steel tubular columns under unequal load eccentricities, Journal of Constructional Steel Research 2012; 68:107-117.

[33] Hernández-Figueirido D, Romero ML, Bonet, JL, Montalvá JM. Influence of Slenderness on High-Strength Rectangular Concrete-Filled Tubular Columns with Axial Load and Nonconstant Bending Moment, J. Struct. Eng. 2012; 138(12): 1436-1445.

[34] Espinos A, Romero M L, Portolés J M, Hospitaler A. Ambient and fire behavior of eccentrically loaded elliptical slender concrete-filled tubular columns. Journal of constructional steel research 2014;100:97-107.

[35] Espinós A, Romero M, Serra E, Hospitaler A., Fire performance of circular and square slender concrete filled tubular columns subjected to large eccentricities, Journal of Constructional Steel Research 2014, (under review).

[36] Lennon T, Moore DB, Wang YC, Bailey CG. Designers' guide to EN 1991-1-2, EN 1992-1-2, EN 1993-1-2 and EN 1994-1-2. Thomas Telford Limited; 2007.

[37] Leskela MV. Inconsistencies in the fire design rules of composite columns to EN 1994-12. Steel Concrete Composite and Hybrid Structures, pp. 489-494. Leeds, England; 2009.

[38] European Comittee of Standarization, EN 1993-1-1:2005 Eurocode 3 Design of steel structures. Part 1-1. General rules., 2005. 
Romero M.L., Espinos A, Portolés JM, Hospitaler A and Ibañez C, Slender double-tube ultrahigh strength concrete-filled tubular columns under ambient temperature and fire, Engineering Structures 2015; 99: 536-545.

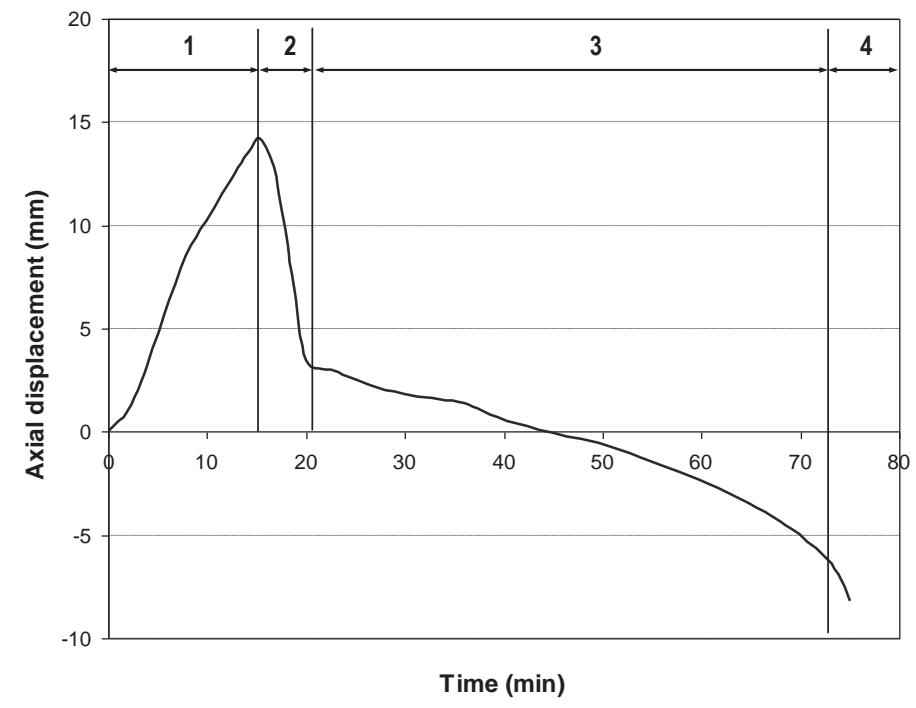

Fig. 1. Axial displacement versus time curve, from Espinos et al [4] 
Romero M.L., Espinos A, Portolés JM, Hospitaler A and Ibañez C, Slender double-tube ultrahigh strength concrete-filled tubular columns under ambient temperature and fire, Engineering Structures 2015; 99: 536-545.

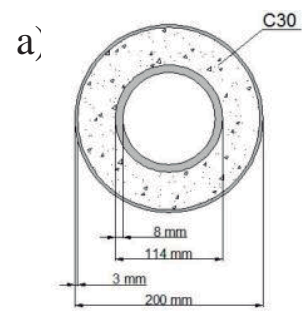

C200-3-30_C114-8-00

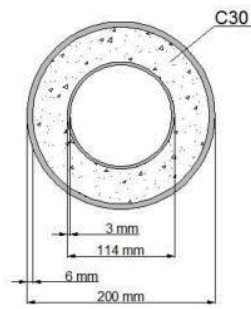

C200-6-30_C114-3-00

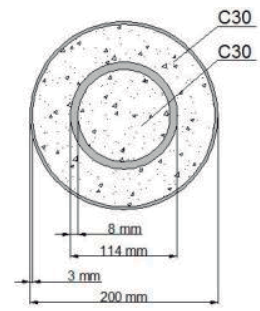

C200-3-30_C114-8-30

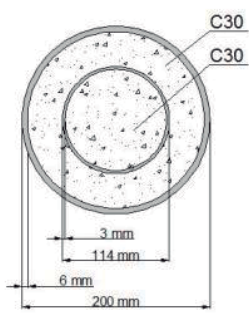

C200-6-30_C114-3-30

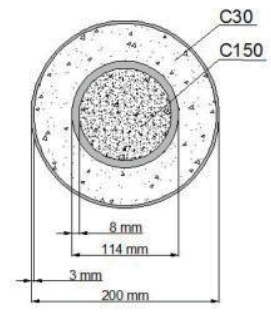

C200-3-30_C114-8-150

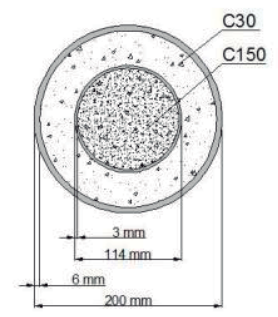

C200-6-30_C114-3-150 b)
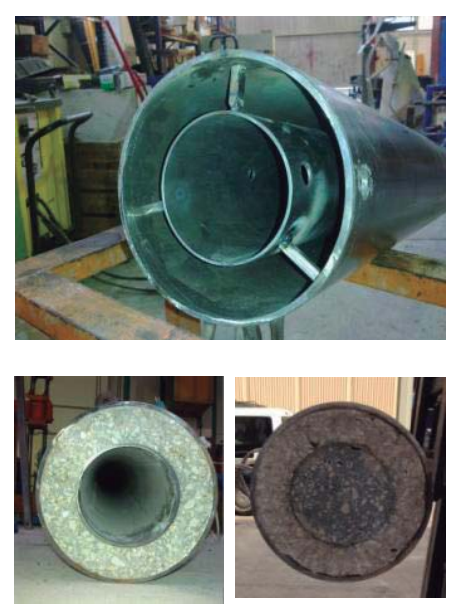

d)

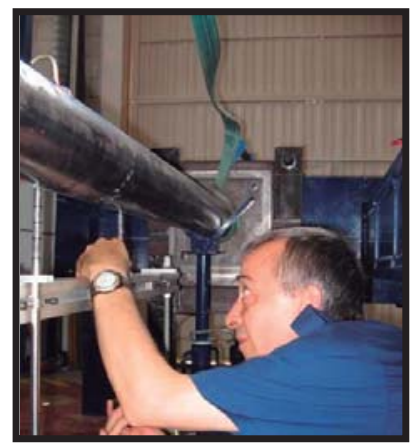

Fig. 2. Room temperature tests: a) Cross-sectional dimensions. b) Details of the crosssections. c) test set-up at room temperature d) LVDT's 
Romero M.L., Espinos A, Portolés JM, Hospitaler A and Ibañez C, Slender double-tube ultrahigh strength concrete-filled tubular columns under ambient temperature and fire, Engineering Structures 2015; 99: 536-545.

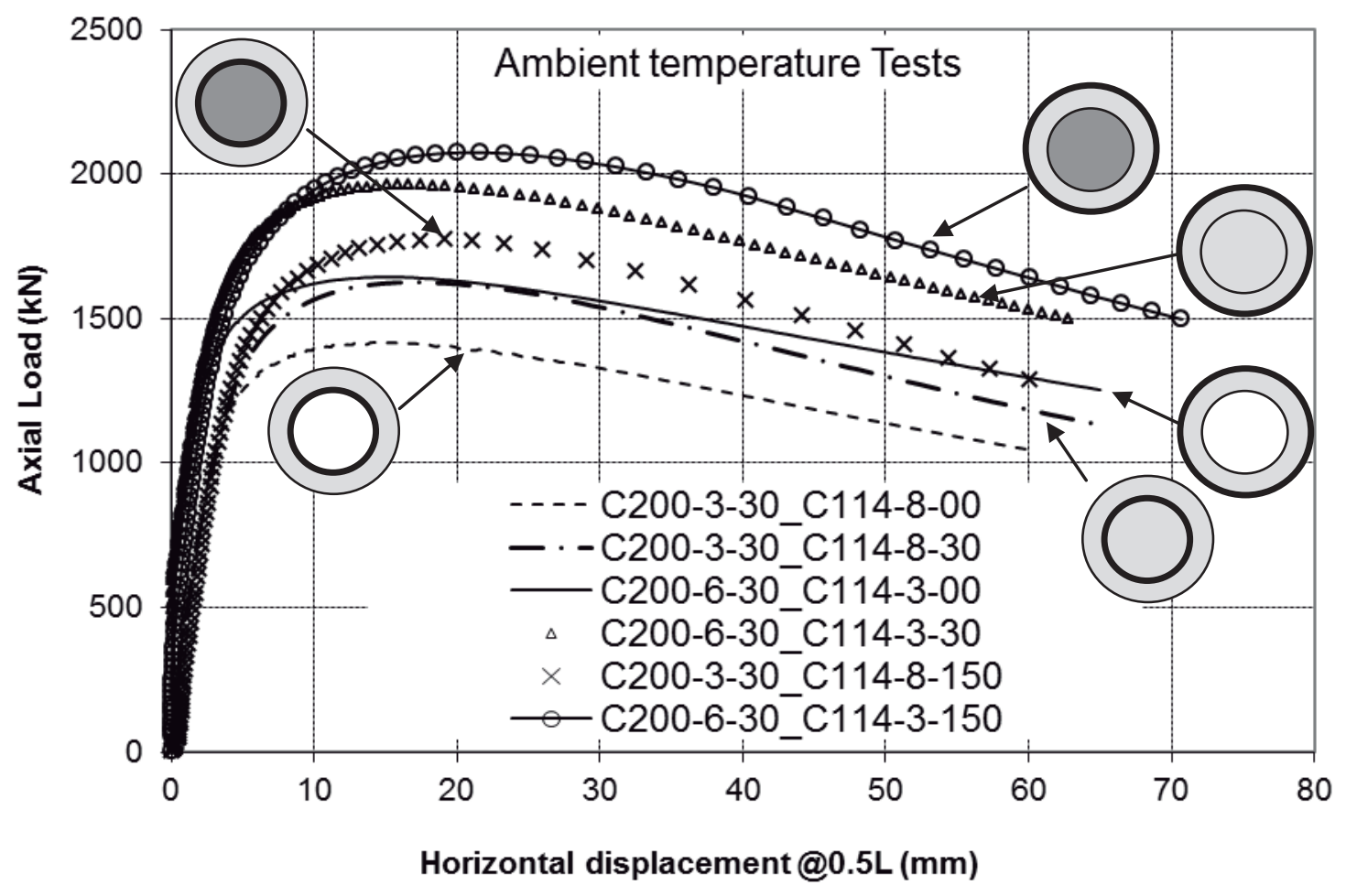

Fig. 3. Load versus lateral displacement curves for the ambient temperature tests 
Romero M.L., Espinos A, Portolés JM, Hospitaler A and Ibañez C, Slender double-tube ultrahigh strength concrete-filled tubular columns under ambient temperature and fire, Engineering Structures 2015; 99: 536-545.
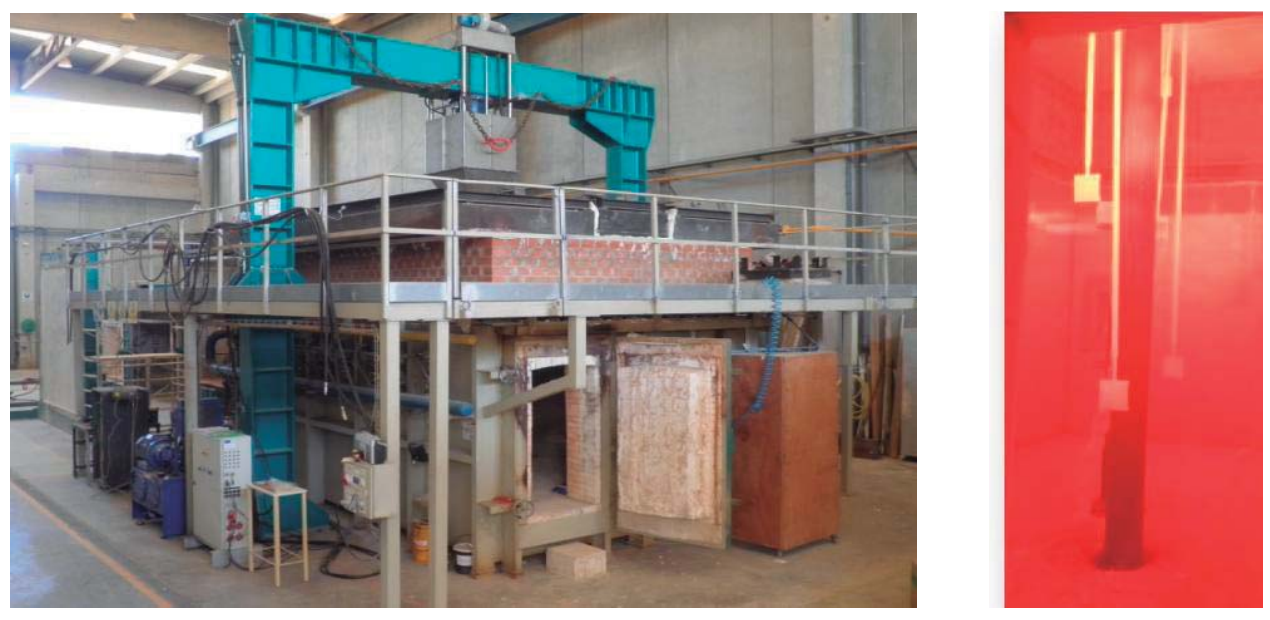

Fig. 4. Fire tests a) View of the testing furnace b) Column during fire test 
Romero M.L., Espinos A, Portolés JM, Hospitaler A and Ibañez C, Slender double-tube ultrahigh strength concrete-filled tubular columns under ambient temperature and fire, Engineering Structures 2015; 99: 536-545.

a)

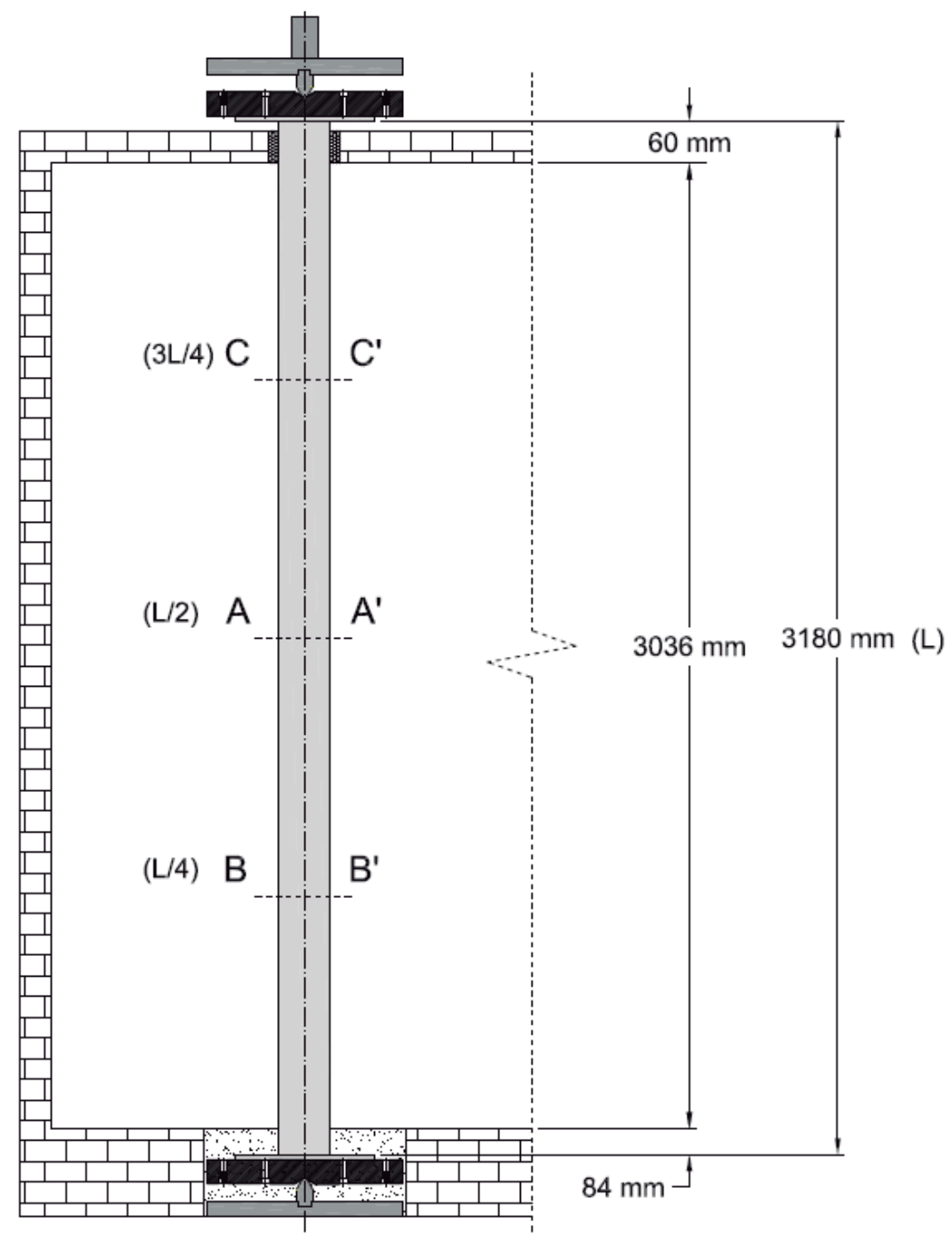

b)

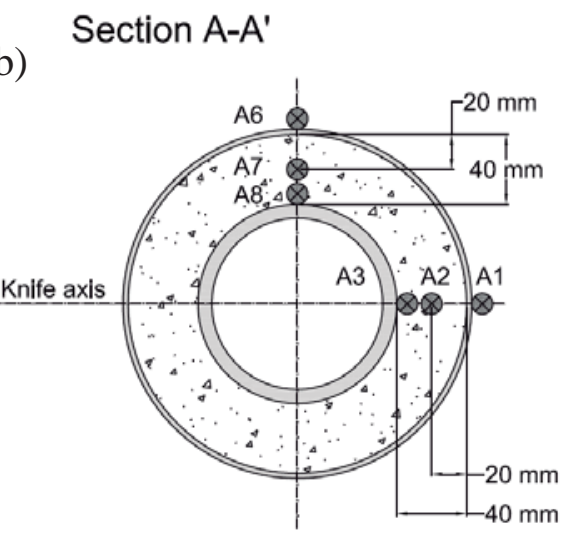

c) Section A-A'

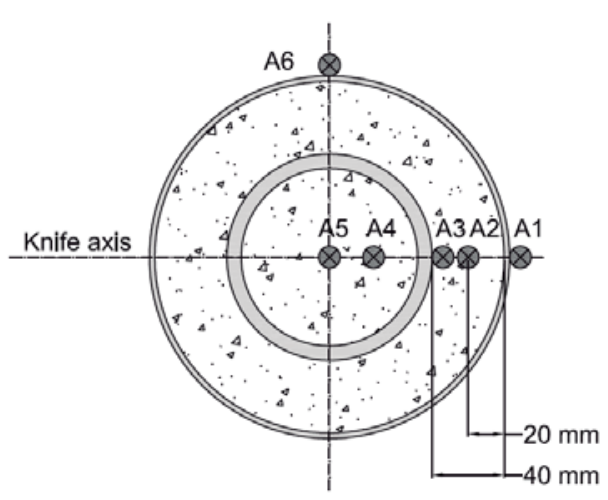

Fig. 5. Fire tests setup a) Schematic view of the column inside the furnace; $b$ ) thermocouple location at section A-A' of column C200-3-30_C114-8-0 c) thermocouple location at section A-A' of column C200-3-30_C114-8-150 
Romero M.L., Espinos A, Portolés JM, Hospitaler A and Ibañez C, Slender double-tube ultrahigh strength concrete-filled tubular columns under ambient temperature and fire, Engineering Structures 2015; 99: 536-545.

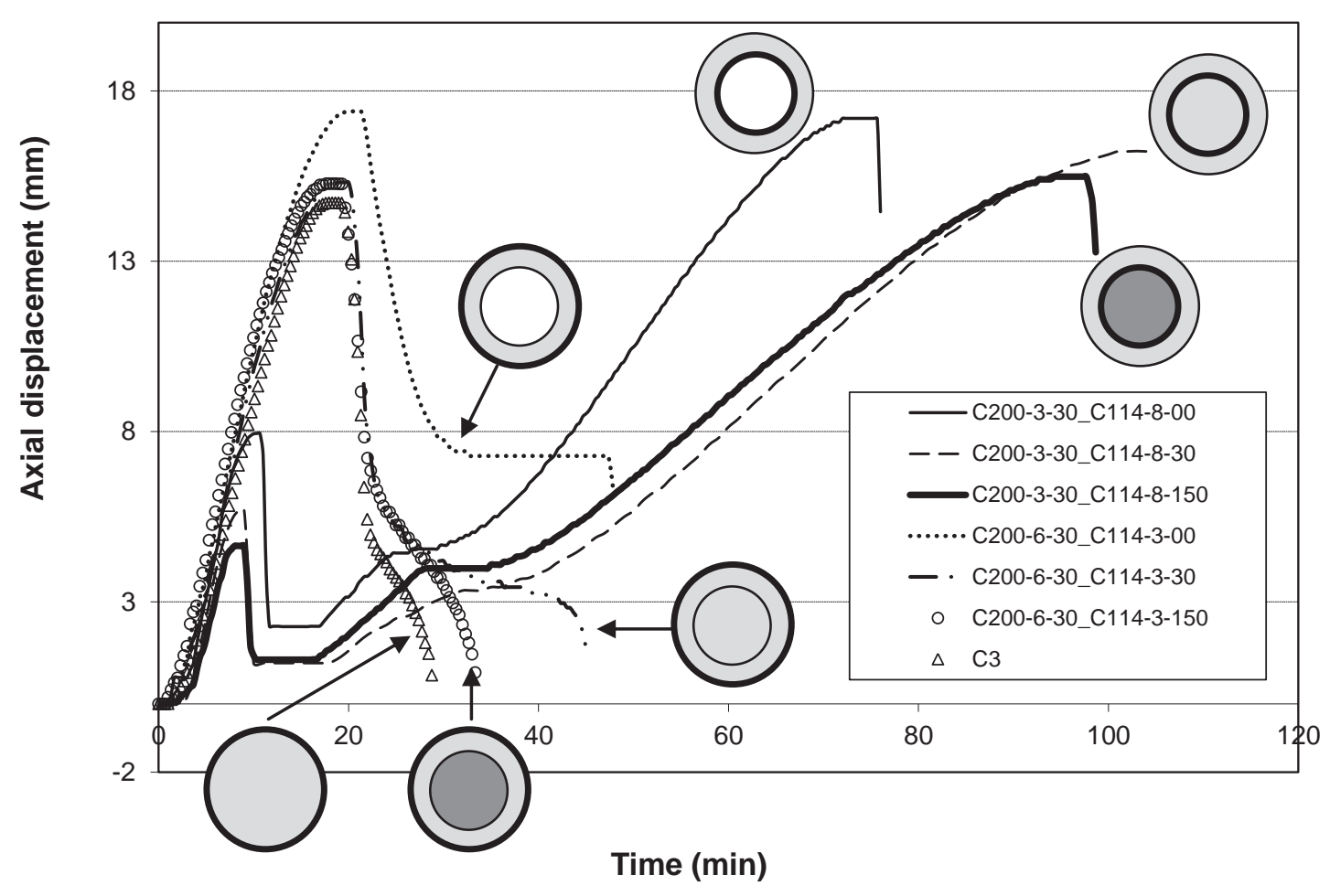

Fig. 6. Axial elongation versus time curves for the fire tests 
Romero M.L., Espinos A, Portolés JM, Hospitaler A and Ibañez C, Slender double-tube ultrahigh strength concrete-filled tubular columns under ambient temperature and fire, Engineering Structures 2015; 99: 536-545.

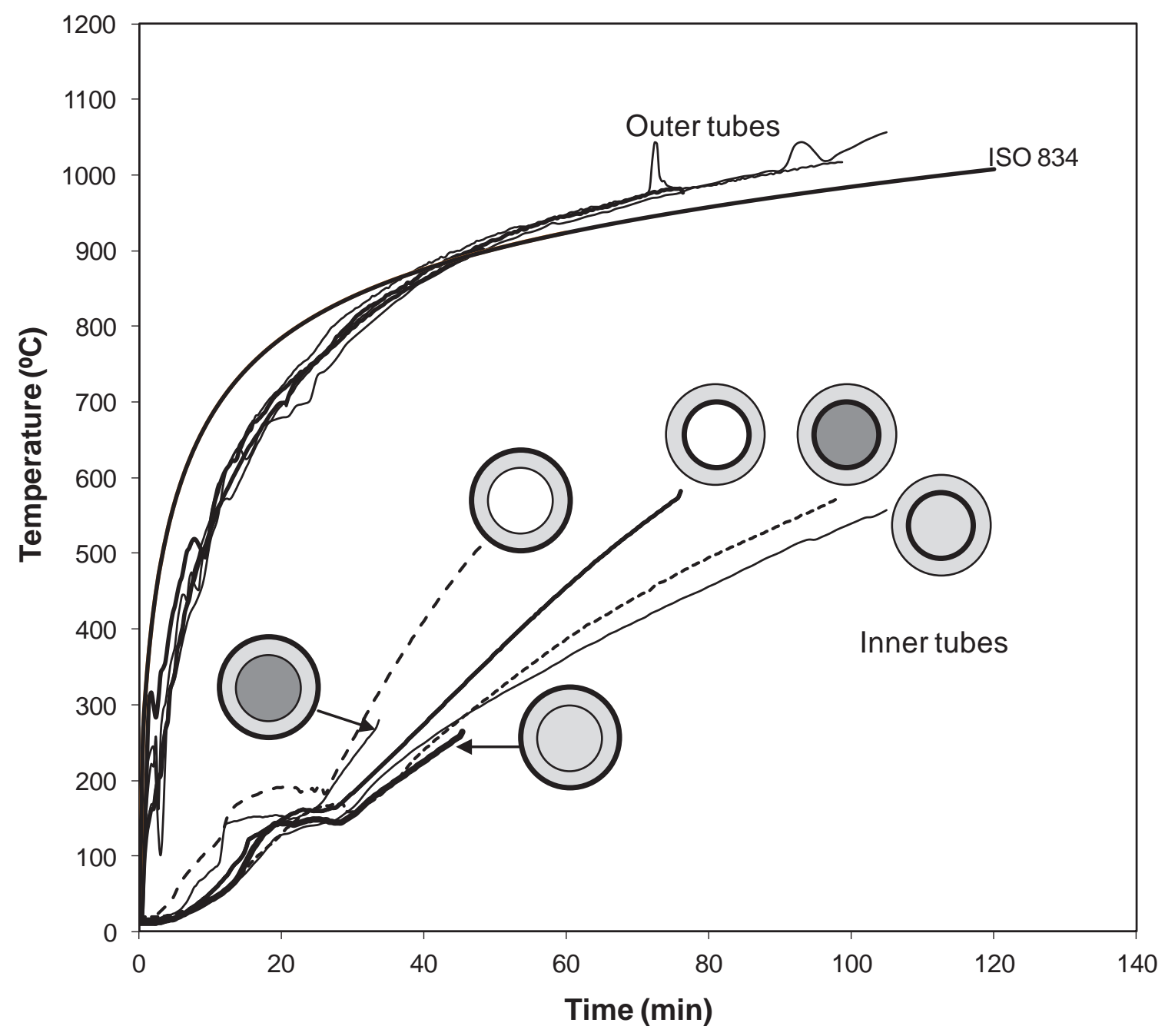

Fig. 7. Distribution of temperatures in the inner tubes. 
Romero M.L., Espinos A, Portolés JM, Hospitaler A and Ibañez C, Slender double-tube ultrahigh strength concrete-filled tubular columns under ambient temperature and fire, Engineering Structures 2015; 99: 536-545.

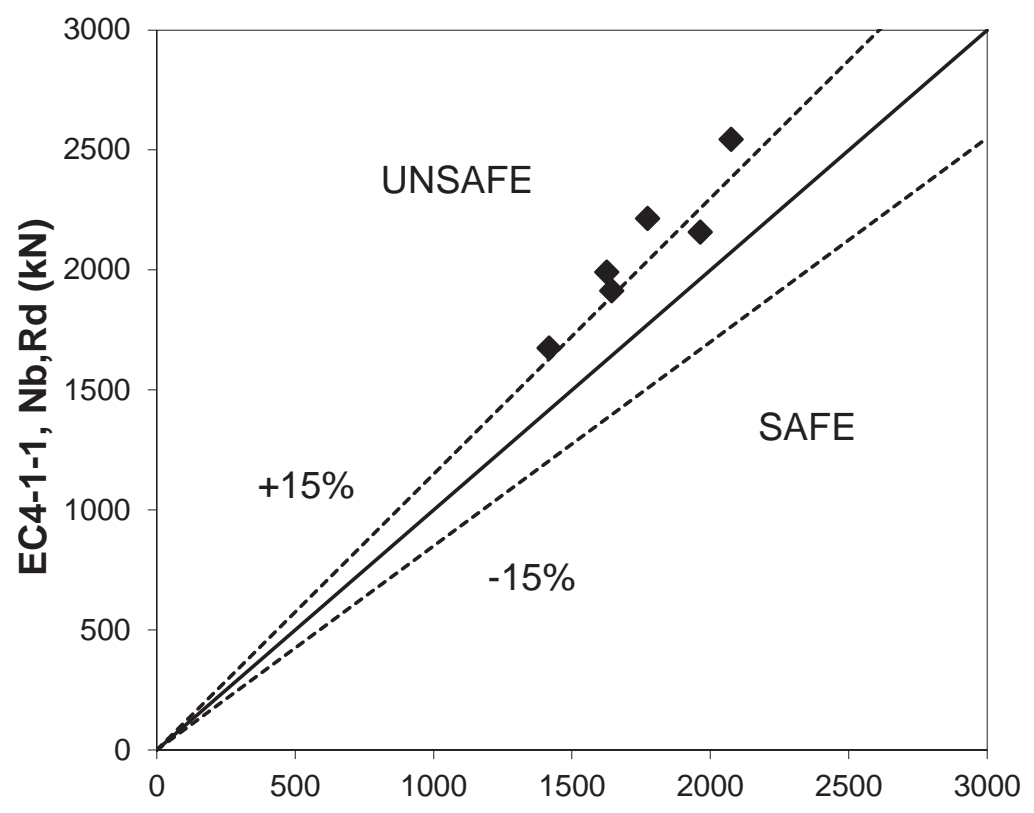

Test results, $\mathrm{Nu}(\mathrm{kN})$

a)

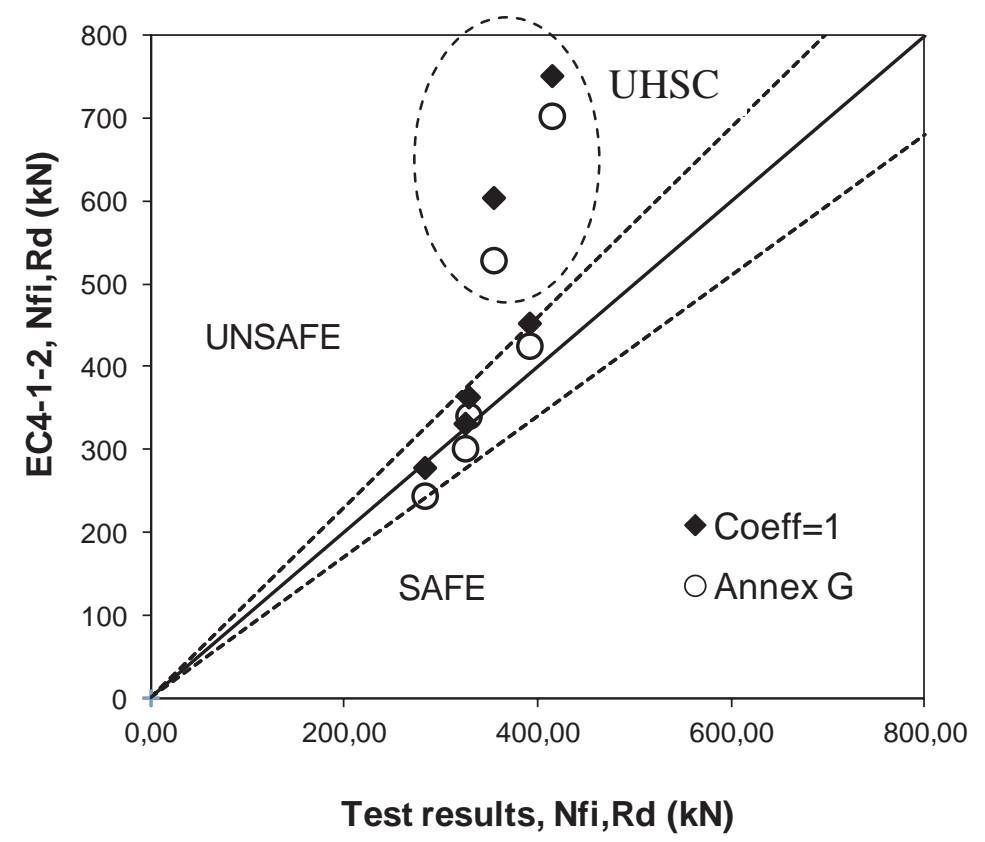

b)

Fig. 8. Comparison between calculated buckling load (EC4) and test load a) Room Temperature b) Fire 
Romero M.L., Espinos A, Portolés JM, Hospitaler A and Ibañez C, Slender double-tube ultrahigh strength concrete-filled tubular columns under ambient temperature and fire, Engineering Structures 2015; 99: 536-545.

Table 1. Details of the column specimens and test results

a) Room temperature

\begin{tabular}{|c|c|c|c|c|c|c|c|c|c|c|}
\hline & \multicolumn{4}{|c|}{ Outer Tube } & \multicolumn{4}{|c|}{ Inner Tube } & Exp & EC4 \\
\hline Column specimen & $\begin{array}{l}\mathrm{D}_{\text {ext }} \\
\mathrm{mm}\end{array}$ & $\begin{array}{l}\mathrm{t}_{\text {ext }} \\
\mathrm{mm}\end{array}$ & $\begin{array}{l}f_{\mathrm{y}, \mathrm{ext}} \\
\mathrm{MPa}\end{array}$ & $\begin{array}{l}\mathrm{f}_{\mathrm{c}, \mathrm{ext}} \\
\mathrm{MPa}\end{array}$ & $\begin{array}{l}\mathrm{D}_{\text {int }} \\
\mathrm{mm}\end{array}$ & $\begin{array}{l}\mathrm{t}_{\text {int }} \\
\mathrm{mm}\end{array}$ & $\begin{array}{l}\mathrm{f}_{\mathrm{y}, \text { int }} \\
\mathrm{MPa}\end{array}$ & $\begin{array}{l}\mathrm{f}_{\mathrm{c}, \mathrm{int}} \\
\mathrm{MPa}\end{array}$ & $\begin{array}{l}\mathrm{N}_{\mathrm{u}} \\
\mathrm{kN}\end{array}$ & $\begin{array}{l}\mathrm{N}_{\mathrm{b}, \mathrm{Rd} d} \\
\mathrm{kNN}\end{array}$ \\
\hline C200-3-30-C114-8-00 & 200 & 3 & 300 & 36 & 114.3 & 8 & 377 & 00 & 1418 & 1674 \\
\hline $\mathrm{C} 20$ & 200 & 3 & 332 & 45 & 114 & 8 & 403 & 42 & 1627 & 1990 \\
\hline$-\mathrm{C} 114-8-150$ & 200 & 3 & 272 & 43 & 114.3 & 8 & 414 & 134 & 1774 & 2213 \\
\hline $\mathrm{C} 200$ & 200 & 6 & 407 & 35 & 114.3 & 3 & 343 & 00 & 1644 & 1912 \\
\hline & 200 & 6 & 377 & 44 & & 3 & 329 & 40 & 1964 & 2156 \\
\hline C200-6-30-C114-3-150 & 200 & 6 & 386 & 43 & 114.3 & 3 & 343 & 123 & 2076 & 2543 \\
\hline
\end{tabular}

b) Fire

\begin{tabular}{|c|c|c|c|c|c|c|c|c|c|}
\hline & \multicolumn{4}{|c|}{ Outer Tube } & \multicolumn{4}{|c|}{ Inner Tube } & $\begin{array}{l}\text { Fire } \\
\text { tests }\end{array}$ \\
\hline Column specimen & $\begin{array}{l}\mathrm{D}_{\text {ext }} \\
\mathrm{mm}\end{array}$ & $\begin{array}{l}\mathrm{t}_{\mathrm{ext}} \\
\mathrm{mm}\end{array}$ & $\begin{array}{l}f_{y, e x t} \\
\text { MPa }\end{array}$ & $\begin{array}{l}\mathrm{f}_{\mathrm{c}, \mathrm{ext}} \\
\mathrm{MPa}\end{array}$ & $\begin{array}{l}\mathrm{D}_{\text {int }} \\
\mathrm{mm}\end{array}$ & $\begin{array}{c}\mathrm{t}_{\mathrm{int}} \\
\mathrm{mm}\end{array}$ & $\begin{array}{l}\mathrm{f}_{\mathrm{y}, \text { int }} \\
\mathrm{MPa}\end{array}$ & $\begin{array}{l}\mathrm{f}_{\mathrm{c}, \mathrm{int}} \\
\mathrm{MPa}\end{array}$ & $\begin{array}{cc}\mathrm{N}_{\text {fire }} & \mathrm{FR} \\
\mathrm{kN} & \mathrm{min}\end{array}$ \\
\hline C200-3-30-C114-8-00 & 200 & 3 & 300 & 46 & 114.3 & 8 & 377 & 00 & 283 \\
\hline C200-3-30-C114-8-30 & 200 & 3 & 332 & 46 & 114.3 & 8 & 403 & 45 & 325 \\
\hline C200-3-30-C114-8-150 & 200 & 3 & 272 & 44 & 114.3 & 8 & 414 & 136 & 355 \\
\hline C200-6-30-C114-3-00 & 200 & 6 & 407 & 43 & 114.3 & 3 & 343 & 00 & 329 \\
\hline 30-C114-3-30 & 200 & 6 & 377 & 44 & 114.3 & 3 & 329 & 42 & 392 \\
\hline C200-6-30-C114-3-150 & 200 & 6 & 386 & 43 & 114.3 & 3 & 343 & 126 & 415 \\
\hline C3* & 194 & 8 & 359 & 43 & $6 \phi 12$ & & 512 & & 535 \\
\hline
\end{tabular}

$\mathrm{t}=$ thickness $\quad \mathrm{D}=$ diameter $\quad$ B.C.= pinned-pinned

* test from [35] 
Romero M.L., Espinos A, Portolés JM, Hospitaler A and Ibañez C, Slender double-tube ultrahigh strength concrete-filled tubular columns under ambient temperature and fire, Engineering Structures 2015; 99: 536-545.

Table 2. Summary of the results obtained with EC4 Part 1.2 calculation method (fire tests)

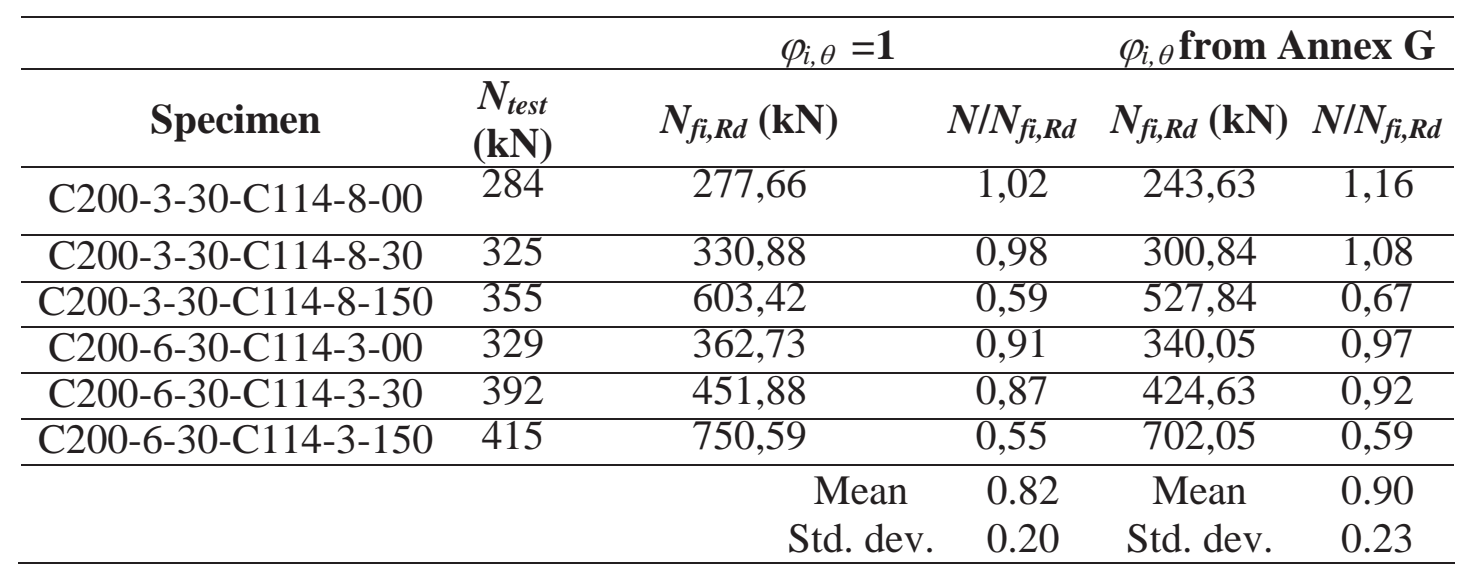




\section{LIST OF FIGURE CAPTIONS}

Fig. 1. Axial displacement versus time curve, from Espinos et al [4]

Fig. 2. Room temperature tests: a) Cross-sectional dimensions. b) Details of the crosssections. c) test set-up at room temperature d) LVDT's

Fig. 3. Load versus horizontal displacement curves for the ambient temperature tests

Fig. 4. Fire tests a) View of the testing furnace b) Column during fire test

Fig. 5. Fire tests setup a) Schematic view of the column inside the furnace; b) thermocouple location at section A-A' of column C200-3-30_C114-8-150

Fig. 6. Axial elongation versus time curves for the fire tests

Fig. 7. Comparison between calculated buckling load (EC4) and test load a) Room Temperature b) Fire

\section{LIST OF TABLE CAPTIONS}

Table 1. Details of the column specimens and test results

Table 2. Summary of the results obtained with EC4 Part 1.2 calculation method (fire tests) 